\title{
Article \\ The Letters of Marshall McLuhan and Pierre Elliott Trudeau: Privacy/Private Matters
}

\author{
Elaine Kahn
}

check for updates

Citation: Kahn, Elaine. 2021. The Letters of Marshall McLuhan and Pierre Elliott Trudeau: Privacy/

Private Matters. Laws 10: 42

https://doi.org/10.3390/laws10020042

Received: 20 April 2021

Accepted: 19 May 2021

Published: 29 May 2021

Publisher's Note: MDPI stays neutral with regard to jurisdictional claims in published maps and institutional affiliations.

Copyright: (c) 2021 by the author. Licensee MDPI, Basel, Switzerland. This article is an open access article distributed under the terms and conditions of the Creative Commons Attribution (CC BY) license (https:// creativecommons.org/licenses/by/ $4.0 /)$.
Independent Researcher, Teaneck, NJ 07666, USA; elainebkahn@gmail.com

\begin{abstract}
There has been a paradigm shift in global communications since the death many years ago of prominent Canadians Marshall McLuhan and Pierre Elliott Trudeau. The correspondence between the two friends, from 1968 to 1980, presciently touched on our contemporary wired global village and the challenges it presents to personal privacy and to freedom of expression. I examine the relationship between the two men, as laid out in their letters and, to a lesser extent, in secondary sources, highlighting matters of privacy and media. Privacy hovers over the correspondence, even when it is not the stated topic. McLuhan, who is credited with the term "global village", discussed with Trudeau the effect of new media on people's notions of tribe and identity and privacy. Proving a direct influence from one man to the other, in either direction, is not possible, but there is much to play with. The gap is, as McLuhan often said, "where the action is".
\end{abstract}

Keywords: McLuhan; Trudeau; private; public; media; privacy; identity; global

"Under electric conditions there can be no privacy", wrote master media interpreter Marshall McLuhan on 16 April 1968, in his first letter to incoming Canadian prime minister Pierre Elliott Trudeau. "The privacy invaders are the bulwark of the new knowledge industries, from the polsters [sic], to the insurance companies, and the credit ratings, 'the eye in the sky,' the age of the 'snoop'" (Kahn 2019). ${ }^{1}$

In 1961, Trudeau had written that identity cards were a bad idea which would result in every citizen having "to be constantly ready to justify his presence, his actions, and his conditions to an authority: the State, the Office, the Police, the Boss" (Trudeau 1968). 2,3

Such prescient comments by both of these globally renowned Canadians resonate thunderously in the totally surveilled, almost completely wired world of 2021, with the possibility of global identification cards a threatened norm masquerading as a reward for those who have been vaccinated against a global disease. Yet the comments also feel unsettlingly matter of fact, describing the consequences of technologies already in place or those that would be willingly activated and accepted as soon as they were available. The comments do not feel cautionary. It had been less than a dozen years since Sputnik.

"The twenty-first century will be the age of Aquarium [sic], by common consent", McLuhan later wrote (McLuhan and Powers 1989). "Omnipresence has become an ordinary human dimension"(McLuhan 2003a). ${ }^{5}$

\section{Introduction}

In this paper, based on the McLuhan-Trudeau correspondence, which began right after Trudeau became federal Liberal party leader in April 1968 and ended with McLuhan's death in 1980, I poke at their discussions of the private and the public and, to a lesser

\footnotetext{
(Kahn 2019), Been Hoping, p. 73.

(Trudeau 1968), "The Identity Card is Back", in Against the Current, pp. 112-13.

(Bilefsky and Austen 2019), "Scandal."

(McLuhan and Powers 1989), Global Village, p. 92.

(McLuhan 2003a), Probes, p. 328.
} 
extent, of media and image making. I reach no surprising conclusions-their interest in these topics is well known. As with McLuhan's own work, the fun is in the probing.

That these men were Canadians probably influenced their ideas about privacy, in both their personal and public lives. For many years, it was a truism outside the U.S. that Americans, unlike Canadians, would tell you their entire life story, in detail, the first time they met you. In the wired world, this sharing is no longer particularly American; "One study found that people share four times as much information about themselves when they converse through computers as when they talk in person" (Carr 2017). ${ }^{6}$

Another truism years ago was that Canada was always in many ways a generation "behind" the U.S. Today, it is the area of privacy in public policy in which Canada needs to catch up. According to lawyer Kirsten Thompson,

“... Canada's approach needs to find a balance between the laissez-faire approach of the United States and Europe's more stringent privacy regulations.

"I'm not sure we want to go as far as (the European Union), which puts the emphasis on human rights protection, and I suspect that neither do we want to go in the direction that the U.S. takes, which is laissez-faire capitalism", said Thompson, who represents companies navigating Canada's privacy laws.

"Canada is somewhere in the middle of that", she said. "Getting that balance right is going to be critical" (Boutilier 2020). ${ }^{7}$

Deep concerns about privacy, regarding personal tracking devices, surveillance and medical information, grew and spread globally with the outbreak of the 2020 pandemic; even as lockdowns were put in place worldwide in various forms, the New York Times announced that "Privacy Is Seen As Early Victim Of the Outbreak"(Singer and Sang-Hun 2020). ${ }^{8}$ That headline seems laughably naïve; we have been clicking our privacy away for decades. In 1967, McLuhan wrote that

"Electrical information devices for universal, tyrannical womb-to-tomb surveillance are causing a very serious dilemma between our claim to privacy and the community's need to know. The older, traditional ideas of private, isolated thoughts and actions-the patterns of mechanistic technologies-are very seriously threatened by new methods of instantaneous electric information retrieval, by the electrically computerized dossier bankthat one big gossip column that is unforgiving, unforgetful and from which there is no redemption, no erasure of early "mistakes"(McLuhan 2003b). ${ }^{9}$

Many of the McLuhan-Trudeau letters mix the public-thoughts or advice that could be shared further, usually without negative consequences-with the private or the personal. A good example is Trudeau's 25 February 1973 reply to McLuhan's very insightful comments about the ways the prime minister was perceived by Canada's English and French communities. Unlike the rest of the correspondence, this letter was handwritten and on Trudeau's personal stationery:

Dear Marshall:

I found your letter of February 12th very perceptive, as usual, but also applicable to my immediate actions. I plan to reflect on it, when next considering any public appearances. Perhaps, I could even give a talk (in Ottawa) on the importance of the two publics you describe seeing "each other at the same time that they are watching (me)".

Many thanks for your thoughts and prayers. God bless.

Pierre (Kahn 2019) ${ }^{10}$

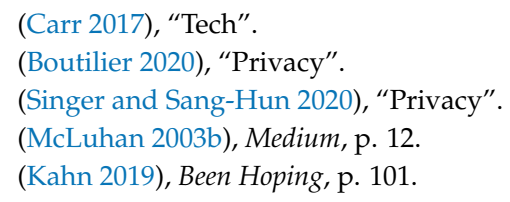


McLuhan, born in Edmonton, never stopped thinking of himself as a Western Canadian. His perceptions about Canada were perhaps more piercing for being off-center. In an early letter to figure out how to set up opportunities to give the prime minister advice about the workings of media and using media to best advantage, McLuhan wrote, "One theme that may have some immediate relevance: Canada is the only country in the world that has never had a national identity. In an age when all homogenous nations are losing their identity images through rapid technological change, Canada alone can 'keep its cool.' We have never been committed to a single course or goal. This is our greatest asset ..." (Kahn 2019). ${ }^{11}$

Trudeau too had never been committed to a single course in his life (McLuhan was a lifelong professor, spending most of his career at the University of Toronto). He was better known and understood in Quebec when he came into national prominence, which he did at a time that was right for both him and the country, "Trudeau functioned as sort of a blank slate on which Canadians wrote their hopes, fears, anxieties, frustrations, aspirations and anger", not the usual Canadian politician, but "a mythical figure, the sort of figure who is able, however briefly, to transcend a group's internal divisions, resolve its many contradictions, and reveal its inchoate destinies"(2009). ${ }^{12}$

The two men were aware of each other for years before their working relationship and friendship began and warmed up over time. One biographer writes that McLuhan first noticed Trudeau in the 1950s, when he was, among other things, a media commentator in Quebec (Ricci 2009). ${ }^{13}$ The Trudeau papers in Ottawa at Library and Archives Canada (LAC) include a photocopy from the 21 November 1965 New York World Journal Tribune. A handwritten notation in a 3 July 1968 letter from Trudeau to McLuhan refers to a brief encounter in June 1964 in Charlottetown (likely at the annual meeting of the Canadian Political Science Association) (Clarkson and McCall 1990). ${ }^{14}$ In an October 2020 lecture at McGill University, SUNY professor Jonathan Slater said McLuhan sent Trudeau his paper on the Royal Commission on Bilingualism and Biculturalism while Trudeau was still teaching law at the Université de Montreal, a move I imagine was prompted by the brief encounter in Charlottetown. ${ }^{15}$

McLuhan's papers are also at LAC but, even with help from skilled archivists, paper trails are not always easy to trace. The world's underappreciated archives are "an irreplaceable witness to past events, underpinning democracy, the identity of individuals and communities, and human rights"(Lomas 2019) ${ }^{16}$ but there can be gatekeepers to appease to get access to specific collections and there are institutional rules and restrictions, though no universal standards, about which records are restricted and for how many years. In 2019, Canadians were stunned to learn that, 30 years earlier, the Canadian Security Intelligence Service had destroyed its secret dossier on Trudeau, rather than turning it over to LAC (Bronskill 2019). ${ }^{17}$

For archives, there are issues of privacy, secrecy and public rights and, going forward, the knowledge that "digital data may not have the same qualities of endurance as paper records" (Lomas 2019). ${ }^{18}$ It would be best if the process of moving data from one medium to another were completely reimagined, rather than by "trying to bolt the paper processes onto the digital world" (Findlay 2013). ${ }^{19}$

Privately, Trudeau and McLuhan were good friends, but the paper-based correspondence does include some political advice about putting a bit of distance between them.

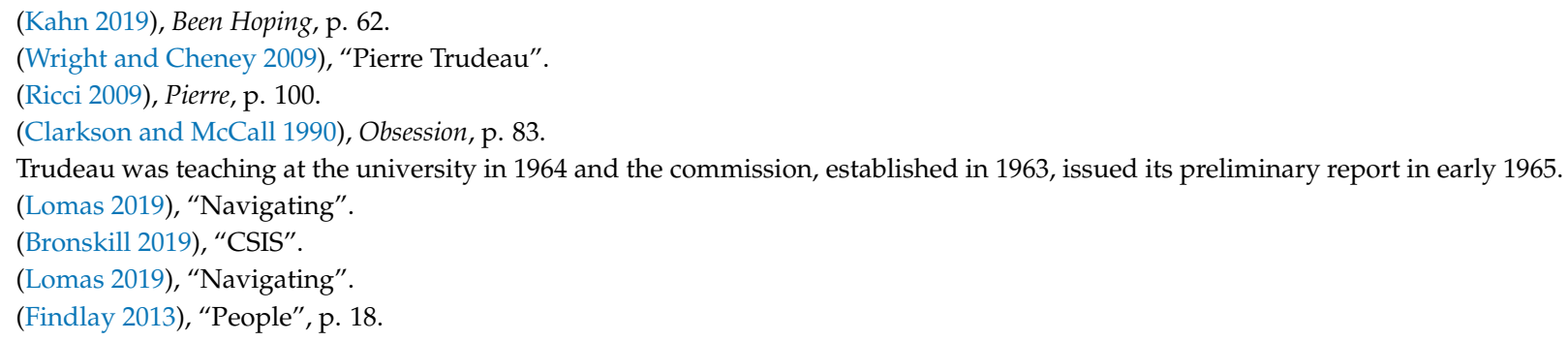


One way to do this was to have an intermediary-in this case, Jim Davey, a member of Trudeau's inner circle of advisers who was himself attracted to McLuhan's ideas. On 13 December 1968, (Kahn 2019) ${ }^{20}$ Davey sent a memorandum to the prime minister via Marc Lalonde, Trudeau's principal secretary and close friend, noting that

"... The periodic comments from Dr. McLuhan have been fascinating and often illuminating. He is a man of immense capacity and great gifts of insight, but he is far enough out in the future that it is difficult to discuss usefully current problems with him. I believe that we can get the greatest value from the horizons that he can open to our thinking rather than illumination of the path immediately ahead.

"Perhaps you think otherwise, but I believe that Dr. McLuhan may be hard to handle if the contact is too frequent and too close. What would be helpful would be occasional correspondence and a lunch once or twice a year in which he could open up over a broad range of subjects" ${ }^{21}$

There may not have been a meeting of the minds; "McLuhan was never quite convinced that Trudeau actually understood anything he said" (Marchand 1998). ${ }^{22}$ McLuhan's work is not science, but a method of perception. As he told Canadian cultural journalist Robert Fulford, " ... [I]nsights are not points of view. I do not have a point of view on anything. I am interested only in modalities and processes" (Molinaro et al. 1987). ${ }^{23}$

As time went on, Trudeau began offering his own views of McLuhan's ideas and the tone of the correspondence became warmer, with both men signing off with terms like "God bless ... " or "I'll keep you in my prayers" or other religious references, even as Trudeau's own religious beliefs and observances remained private in public. Both men were Catholic - the prime minister by birth, McLuhan by choice. McLuhan's attendance at daily mass was public knowledge at the University of Toronto college where he taught but, as is common in academia, he largely kept his Catholicism out of the classroom.

Some time in the 1970s, religion became privatized in Canada. This is a condition well beyond the firmly established one of the separation of church and state. Religion became something that individuals did or, much more often, did not do, entirely by themselves, like a private passion for orchids or for old maps. In public discourse, it became virtually an irrelevancy (English et al. 2004). ${ }^{24}$

Trudeau was known for his "famously fiercely guarded sense of privacy, that noli me tangere quality that kept almost everyone at their distance, except a few intimate friends ... " (English et al. 2004). ${ }^{25}$ However, I have found no reason to think Trudeau disliked media exposure per se and, of course, " ... [F]or an intensely private man, he chose a way of life that splatted his life all over the place" (English et al. 2004). ${ }^{26}$ He had a certain somewhat ingenuous view of how that might be done, reminiscing that:

"For the most part, I kept a watertight seal between my private life and my public life. I never brought my family problems into my job as prime minister, and I tried never to bring my prime ministerial problems into my life as a parent and husband. I remember when I'd go home and play with my children, it was almost as if "the Prime Minister" was someone other than me ... It really was almost schizophrenic-and it helped me a lot.

"But, unknown to me, some of the political life may have spilled over onto the family life ..." (Trudeau 1993). ${ }^{27}$

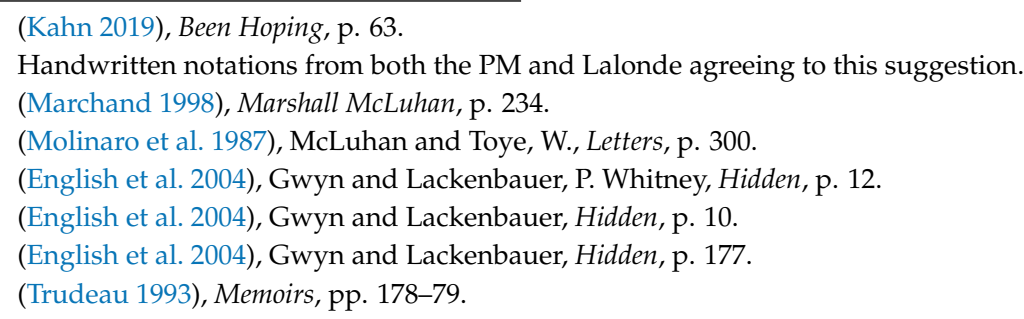




\section{Loosely Defined}

I have selected letters based on their ability to best illuminate categories of media, image, privacy, personal, public/private, and secret, although some fit into more than one. In addition, dictionary definitions of "privacy", "private", "personal" and "secret" have fuzzy boundaries. "Public", though multifaceted, is more clearly defined:

"Privacy" includes "secrecy", "the quality or state of being apart from company or observation" and "freedom from unauthorized intrusion"(Merriam-Webster n.d.). ${ }^{28}$

"Personal" is defined as "of, relating to, or affecting a particular person", or even "carried on between individuals directly"(Merriam-Webster n.d.). ${ }^{29}$

"Public", generally acknowledged to be the opposite of "private", has many nuances, including "exposed to general view", "well-known", "prominent", "of, relating to, or affecting all the people or the whole area of a nation or state", "of or relating to people in general", "popular" and "of, or relating to, business or community interests as opposed to private affairs"(Merriam-Webster n.d.). ${ }^{30}$

"Private" seems to be a tug of war between British and American language. The Shorter Oxford leads with "Of a person: Not holding public office or official position", with subsequent definitions indicating that something private is by definition something which is not open to the public or even performed in public, whereas Merriam-Webster prioritizes "intended for or restricted to the use of a particular person, group, or class".

"Secret" in the Shorter Oxford primarily means "Kept from public knowledge", whereas Merriam notes it can also mean "not acknowledged".

\section{Media}

McLuhan was consulted by members of Trudeau's team, if not directly by Trudeau himself (the record is murky) during Trudeau's run for the leadership of the federal Liberal party, a race he won on 6 April 1968. Trudeau was something new on the political scene and needed to learn and use new ways of dealing with media. As McLuhan wrote to him ten days later:

... The men of the press can work only with people who have fixed points of view and definite goals, policies and objectives. Such fixed positions and attitudes are, of course, irrelevant to the electronic age. Our world substitutes mosaics for points of view and probes for targets ...

... At present I am studying the American political developments, noting the utter conflict between Policies and Images as it concerns the candidates. May not the same thing happen here as in Canada recently? The old political professionals simply exhaust and liquidate themselves by going through the old motions, making room for quite unexpected candidates at the last moment.

Like most Canadians, I am delighted that it happened that way for us and that you are to enter into this complex new role.

With most cordial good wishes and prayers,

$$
\text { Marshall McLuhan (Kahn 2019) }{ }^{31}
$$

Trudeau became prime minister in a U.S. presidential election year. On June 1, Senators Robert Kennedy and Eugene McCarthy held a Democratic primary debate, broadcast on network TV.

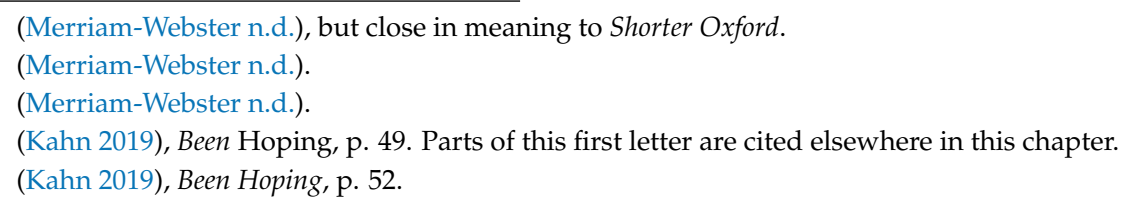




\section{Dear Pierre Trudeau,}

After seeing the Kennedy-McCarthy "debate", I wish that you were not going to be on TV at all. It is not a debating medium (Trudeau 1993). ${ }^{33}$

... The real drama of our age, the shift from hardware services environments of the 19th century to the software (electric information) service environments of the 20th century, is as big a leap as that from primitive tribalism to literate individualism. For our Western world, this is a shift from outer orientation to an inner, oriental trip. It renders all of our institutions obsolete, as the young TV generation fully recognizes ...

... It is not evident that any responsible figure in the Eastern or Western worlds has a clue to the erosion of human identity that follows upon the "software" environment. There is a corresponding release of violence to recover identity after technological innovation. The TV kids cannot accept the identity of their parents' generation so they will simply destroy any institutional or legal attempt to impose it upon them. The liquidation of the feudal system with the advent of printing and gunpowder represented a very slow change from corporate to private identity, compared to the reverse of that process that we are now undergoing ...

Would not a high degree of awareness of these media effects (e.g., radio in Nigeria or in any tribal territory) enable us to set up social therapies and immunizing programs exactly comparable to medical action in the face of an endemic disease? ... 34

$$
\begin{array}{r}
\text { Cordial good wishes for June } 9^{35}, \\
\text { Marshall McLuhan }
\end{array}
$$

McLuhan's thoughts on violence, identity and the speed of technological change echoed in Trudeau's remarks almost three years later at a luncheon in India for Prime Minister Indira Gandhi, when Trudeau said that

"Democracies offer every facility for change. Political and judicial processes are, or should be, geared for change. Yet in this turbulent age in which we live, nation after nation is learning that these processes are too slow, that the rate of actual change outpaces by far the rate of expected change. In that event, as in an electrical system designed in an older, less demanding time, the pressure of the new load becomes so intense that fuses blow and the apparatus breaks down. All too often the flash point is accompanied by violence" (Trudeau 1972). ${ }^{36}$

McLuhan repeatedly pushed Trudeau to understand and involve young people, both because they were important for their own sake and because they were already fans. In this 17 October 1968 letter, (Kahn 2019) ${ }^{37}$ he told the prime minister to engage with high school and university students with an openness that did not come naturally to Trudeau, before advising him to get back onto Canadians' TV screens:

"The time is long overdue for you to be back in circulation and to be in the Canadian living room as a "gap-bridger", the unifying image of our society that you became during the election. It is impossible to exaggerate the advantages in political education that would result. "Government of the air" would by-pass all bureaucracy yet make it possible to consider the problems of bureaucracies of all kinds. Data from government departments

33 This sentenced has been underlined, likely by Trudeau, but he did not follow McLuhan's advice for years. Finally, during his own 1980 election campaign, he refused to debate. (Trudeau 1993), Memoirs, p. 269.

34 Writing this chapter in late 2020, this paragraph connected me to the COVID-19 pandemic, as did the references to masks throughout the correspondence.

35 On June 9, Trudeau would participate in the first political leaders debate ever held during a Canadian election campaign.

36 (Trudeau 1972), Conversation, p. 65.

37 (Kahn 2019), Been Hoping, p. 57. 
could be brought to bear in follow-up sessions. Perhaps it might be more effective to canvass various features of this kind of program by telephone.

"I am prepared to contact the leaders of the student activists on this campus to invite you at once to appear with them on such a program. No preliminary briefing or scripting of any kind would be necessary or desirable. All protocol could be tossed aside. I feel confident that the obvious obstacles to this innovation can be by-passed. This kind of political mountain-climbing could be done in spite of all the obvious road-blocks. The program would not only be a political one but an educational one so far as the C.B.C. is concerned ..." (Kahn 2019). ${ }^{38}$

But events did not proceed as McLuhan had hoped.

13 November 1968 (Kahn 2019) $)^{39}$

\section{Dear Mr. Prime Minister:}

Just a note about media strategy. In your discussion with students from the floor, shown on "The Way It Is" last Sunday, November 10th, you could not have been in a more dangerous position media-wise.

An auditorium violates the very nature of TV, hence the disaster of the political conventions in the U.S.A. Television demands close, casual, intimate discussions. Also no notes, no script, and no debating. The discernment and conception of process prompts total avoidance of debating ...

In my War and Peace book ${ }^{40} \mathrm{I}$ explain how technological change deprives individuals and societies of their identity images, with resulting struggle for new images. In Through the Vanishing Point (which I am taking the liberty of sending you), Harley Parker and I explain how many new kinds of space, psychic and social, result from technological change.

Most cordial good wishes,

Trudeau may not always have followed McLuhan's advice, but he quickly learned some of McLuhan's language. For example, he directly credited McLuhan for "global village" when speaking in the House of Commons in March 1969 (Trudeau 1972) ${ }^{41}$, and during a teach-in at an Australian university in May1970, he noted that "... for the first time in industrial societies ... people today receive their values from their peers. Young people learn values from television, cinema and radio as early as they learn from their parents and as early as they receive them very often from their church. From three or four years on the child is tuned in, plugged in to events happening halfway across the world and he knows them as soon as his parents do and sometimes sooner" (Trudeau 1972) ${ }^{42}$. In a magazine interview a year earlier, he had attributed similar thoughts to McLuhan directly (Trudeau 1972) ${ }^{43}$.

Binding Canadians together through an understanding of each other's identities, primarily but not exclusively meaning the French and English communities, was central to Trudeau's thinking, politics and ideas of constitutional rights.

25 November 1968 (Kahn 2019) ${ }^{44}$

Dear Professor McLuhan:

Thank you for sending to me a copy of your fascinating new book (I had never thought of abstract art as marking the end of visual space; the suggestion is an intriguing one) and for your views on the most effective employment of TV.

38 (Kahn 2019), Been Hoping, p. 58.

9 (Kahn 2019), Been Hoping, p. 60.

War and Peace in the Global Village, written with frequent collaborator Quentin Fiore and published in 1968.

1 (Trudeau 1972), Conversation, p. 166.

2 (Trudeau 1972), Conversation, p. 16.

3 (Trudeau 1972), Conversation, p. 11.

44 (Kahn 2019), Been Hoping, p. 61. 
Understanding the proper use of the media and controlling one's exposure to it are, however, quite distinct as you will appreciate.

The identity process of which you speak so often is one that cannot be ignored by government. I am very much aware of the sometimes search and sometimes struggle for new images in which many communities of our society are engaging. What I lack is an intuitive process to forecast for me the likeliest form of a satisfactory nature which these new images will assume. Can you help me?

Yours sincerely,

Pierre E. Trudeau

Trudeau's critically important reply, with its direct appeal to McLuhan for help, marks the true beginning of friendship, at least on paper. Trudeau was not publicly known for asking for help.

A year earlier, McLuhan had mused that "In an electric information environment, minority groups can no longer be contained-ignored. Too many people know too much about each other. Our new environment compels commitment and participation. We have become irrevocably involved with, and responsible for, each other" (McLuhan 2003b) ${ }^{45}$. In another work that year, he wrote that "... when printing was new, it created what was known as the Public. In the 16th century and after, Montaigne's phrase "le [public]" came into use. The 16th century created the public as a new environment... Electric circuitry did not create the public; it created the mass, meaning an environment of information that involved everybody in everybody" (McLuhan 2016) ${ }^{46}$.

24 January 1969 (Kahn 2019) ${ }^{47}$

Dear Mr. Prime Minister:

Your very cool dealings with our very hot medium the press, naturally produces intense interface or friction. The press has to have hot quotes and sharp points of view. Real news is bad news. Since the press lives on advertising, and all advertising is good news, it takes a lot of bad news to sell all this good news. Even the good news of the gospel can only be sold by hellfire. Vatican II made a very big mistake in this matter as in other matters.

The very cool corporate mask that is your major political asset goes naturally with processing of problems in dialogue rather than in the production of packaged answers. That is why I urge you to go on the air with small groups and to trade problems with them rather than seeking answers or stating mere points of view ...

You are the only political image of our time able to use the T.V. medium without being forced to become a tribal buffoon or cartoon like De Gaulle. All the other political figures of the Western world are merely faded photographs on the T.V. medium.

F.D.R. had the press against him and this was his major asset as long as he relied on radio. But radio is a hot medium and fostered the lecture. T.V. permits audience participation in problem sharing. T.V. is a mini-state that has created various other ones such as the teeny-boppers and the hippies to say nothing of innumerable separatist tribes around the globe.

Most cordial good wishes,

Marshall McLuhan

(McLuhan 2003b), Medium, p. 24.

46 (McLuhan 2016), Nature of Media, p. 122.

47 (Kahn 2019), Been Hoping, p. 65. 
On 4 March 1971, Trudeau married Margaret Joan Sinclair, taking the country, including its media, by surprise, as their relationship had been kept secret from the public. Four days later, McLuhan explained to Jim Davey that

... In this very connection [the media surprise when Trudeau married] I have a new essay, a copy of which I am enclosing, explaining that, why, and how the user is the content of any medium or environment. I am still working on the many features of this situation, and am quite at a loss to explain why I had been unable to see so obvious a fact before. When Trudeau "uses" the media, as in the current nuptial drama, he is their content. When they use him, they are the content. It is a sort of reciprocal hi-jacking ...

... We are the content of anything we use, if only because these things are extensions of ourselves. The meaning of the pencil, or the chair I use is the interplay between me and these things. Again, the message of these things is the sum of the changes that result from their social use. Thus, I have added two features to "the medium is the message", namely the content and the meaning, Perhaps Pierre Juneau or someone at C.R.T.C. would like to have this essay apropos the problem of "Canadian content"? The consequence for the discussion of the problem of Canadian content for the media is drastically simplified by noticing that the user is the content. If Canadians use or watch American programs or drive American cars, it is the Canadians who are the content of these things. The meaning is in the resulting interplay or dialogue between Canadians and these things, but there can be no question that the Canadian user of American things is the content of these things. The meaning and the message are something else. It is unfortunate that the C.R.T.C. ever involved itself in the question of content, especially since it does not understand the nature of media at all, except as hardware ...

... Since the user as content is not a figure of speech but a basic dynamic and cognitative [sic] relationship, I think you will find that it can be pushed all the way as a means of orientation in media, economics and politics. I suggest that it can be the basis for a complete restatement of political and economic realities in the information age of the wired planet.

Cordial greetings,

yrs

Marshall (Kahn 2019) ${ }^{48}$

McLuhan's comment about the Canadian Radio-television and Telecommunications Commission's inability to understand media echoes his 6 May 1969 letter to Jacques Maritain, in which he wrote that "There is a deep-seated repugnance in the human breast against understanding the processes in which we are involved. Such understanding involves far too much responsibility for our actions" (Molinaro et al. 1987) ${ }^{49}$. Both Trudeau and McLuhan were familiar with Maritain's work.

\section{Image}

Trudeau once said, "I couldn't care less about the image. If it's damaging, so much the worse; if it's helpful, so much the better" (Shaw 1969) ${ }^{50}$. His image was instrumental for him, at arm's length from the inner Trudeau who could be hurt.

"... Trudeau entered politics and played the part, considering the camera angles, improvising on occasion, rewriting the lines when they no longer suited his purposes, but dominating the stage, making sure the play went on and in the direction he wanted. This was highly unusual, putting him in the ranks of statesmen like Winston Churchill and

(Kahn 2019), Been Hoping, p. 85.

9 (Molinaro et al. 1987), Letters, p. 370.

50 (Shaw 1969), Gospel, p. 145. 
Charles de Gaulle- those who thought, wrote and were then able to act in consequence" (Clarkson 2000) ${ }^{51,52}$.

One of McLuhan's more well-known notions about Trudeau had to do with the idea of "mask", which he referred to it more than once in his writings to and about the prime minister, as in the 24 January 1969 letter already cited.

$$
12 \text { June } 1968 \text { (Kahn 2019) })^{53}
$$

\section{Dear Pierre Trudeau:}

... Your own image is a corporate mask, inclusive, requiring no private nuance whatever. This is your "cool" TV power. Iconic, sculptural. A mask "puts on" an audience. At a masquerade we are not private persons ...

Very best wishes,

[M.M.]

What some people saw as arrogance in Trudeau —and they may not have been wrongMcLuhan interpreted as a feeling by English Canadians that he had risen too far above his station, that he was acceptable only as a kind of performer (I have not yet found his interpretation of the related meanings inherent in PET, Trudeau's initials and the way he was often referred to in print).

$$
12 \text { February } 1973 \text { (Kahn 2019) } 54
$$

\section{Dear Pierre:}

Just a word about interviews on the subject of your "arrogance". Is it not relevant to ask the interviewer for help in clarifying the problem as it affects the supposed public that is represented by the interviewer? Are there not many hidden factors that the interviewer should explicate as part of his or her job in mediating between you and the public? For example, to the WASP world (white Anglo-Saxon Protestant) your mere existence as head of state is arrogant presumption. That is, for a French Catholic to rule over the "superior and dominant" group, represents to them a kind of reversal of nature, an upsetting of the relation between figure and ground, in gestalt terms.

In a word, there is a wide spread assumption that your arrogance exists in merely occupying your present role. That is, it has nothing to do with your personal image but rather with your corporate role. As long as you were content to "put on" your public by playfulness and "clowning", it was felt that they did not have to take you seriously. As soon as you "play it straight", the WASP public feels abused, since it alone has the right to assume the mask of serious corporate power.

Note how Richard Nixon has ineptly tried to mitigate his crude and harsh image by liaison with various figures in the world of entertainment. He is quite unable to combine these qualities in himself in the way that you have done. To the WASP world the light-hearted approach to power represents aristocratic insouciance and security. The entertainer is a figure which they themselves have crowned. He is permitted to hurt them by his humour, for that is the mask of his power and relevance alike.

A great complication occurs in the matter of your image as it must be presented simultaneously to French and English. Our media totally ignore this fact. The obligations which you have to the French electorate seem to be much at odds with the forming of an image for effective relatedness to the WASP world.

1 (Clarkson 2000), “Charisma”.

52 (Onions 1970).

(Kahn 2019), Been Hoping, p. 53.

54 (Kahn 2019), Been Hoping, p. 100. 
Neither on radio, $\mathrm{TV}$, nor in the press is there ever the slightest hint that this problem exists. You are obliged to perform a balancing act on the high wire for two conflicting publics. It is very important that these publics should see each other at the same time that they are watching you, for their responses to you and to one another are totally diverse.

$$
\begin{array}{r}
\text { Cordially and Prayerfully, } \\
\text { Marshall }
\end{array}
$$

It seems likely that McLuhan was most comfortable among white Catholic men. People of color appear in his writings only as fleeting objects of study or as probes. In one book, the Time magazine photo used to illustrate and explain "global village" is of an unidentified but apparently African group of nude and semi-nude women, men and children, sitting in a circle listening to one of them speak (McLuhan 2003b) ${ }^{55}$. In the letter below, his reference to Black votes is not negative but, throughout his writings, his references to people of color, Jews, women and tribes usually feel bigoted to 21st-century readers; in one such reference, he refers to "the Negro community" as "backward"(McLuhan 1970) ${ }^{56}$. Biographer Philip Marchand wrote that McLuhan directly appealed to the prime minister to freeze the number of "coloured" immigrants entering Canada until there was a policy to help native-born Canadian adjust to that reality, (Marchand 1998) ${ }^{57}$ but this appeal is absent from letters I have seen.

$$
24 \text { February } 1977 \text { (Kahn 2019) })^{58}
$$

\section{Dear Pierre:}

Everybody I know has been deeply thrilled by your recent performance and reception in the U.S. That was a really imaginative and masterly approach, which you brought off superbly.

It was while I was trying to explain charisma, as manifested by Jack Kennedy and also by Jimmy Carter, that I raised the fact of your very powerful charisma. Jack Kennedy looked like the all-American boy, the corporate, inclusive image of American ideals. Nixon, on the other hand, looked like himself alone, a private image, fatally defective in the TV age. In contrast, Jimmy Carter has the charisma of a Huck Finn, a Southern boy, and he also has the vocal rhythms and corporate power that got him the black vote. It was while I was explaining these things that the interviewer asked: "What about Pierre Trudeau?" I replied that your corporate mask, your charisma, is both powerful and very popular with the young, in part because of the subtle hint in your image or "mask" of the native Indian. As you know, the Red man is very powerful with the TV generation since he is Third World, and they are also Third World. He was always Third World, but they, the young, are having their first experience of it. Naturally, pulled out of the context of this image discussion, it sounds very different, and even derogatory. You know me well enough to know that I would never say anything derogatory about you.

In the case of Carter, it became clear during the election that the image has supplanted the policy. A political point of view is not practical on TV since it is a resonating, multi-positional image, so that any moment of arrest or stasis permits the public to shoot you down...

Given that McLuhan worried that he had insulted the prime minister by suggesting he had Indigenous features, it is fascinating to note that, a few years later, in his speech the

5 (McLuhan 2003b), Medium, p. 66-67.

56 (McLuhan 1970), Culture, p. 102.

57 (Marchand 1998), Marshall McLuhan, p. 235.

58 (Kahn 2019), Been Hoping, p. 131. 
night before the 1980 referendum on Quebec separating from Canada, Trudeau spiritedly "pointed to himself and said, 'I ask you: is this the face of an exclusively European man?' - a reference to the frequent speculation about his own Aboriginal blood" (Ricci 2009) ${ }^{59}$.

1 February 1979 (Kahn 2019) ${ }^{60}$

Dear Pierre:

Your thoughtful reply to my query about what line of thinking lay behind the bilingual policy brought to my mind the familiar phrase of Baudelaire in his Envoi to Les Fleurs du Mal, "Hypocrite lecteur, mon semblable, mon frere". The "lecteur" is the reader of the poem who "puts it on" as a mask through which he looks at the world. (The hypocrite is a mask-wearer.) When the reader "puts on" the poem he inevitably distorts it, and this is reciprocated by the poet, who "puts on" the reader as his "semblable" and his "frere" ...

If a poem has the natural and inevitable power of altering both the reader and the poet and their inter-relationship, how much more is this true of our two languages! The speaker of any language assumes it as a medium or a mask by which he experiences the world in a special way, and by which he relates to people in a very special way. The French tongue as a mask or medium at the federal level has a quite different meaning and function from the same tongue at the private level. A language in the hands of a lawyer or a judge or a bureaucrat has a quite different significance from the same language used by friends or enemies. I suggest that your approach to bilingualism as a means of "language equality" is abstract and objective, but not related to the experiential, subjective level. That is not to say this is a misguided attitude, but it merely indicates that the effects of languages as media are quite different from the input or intended meanings. All inputs have side effects which are usually considered irrelevant by the speaker or sender.

... Corinne and I thought that the Christmas card photo of you and the boys was and is most eloquent and delightful.

Trudeau took up the Rimbaud quote in a later work, wondering what the "'two-face reader, so like me, my brother'" would say about the years his government had been in office if another government had been in power instead. He concluded that, "History cannot be judged by comparison with what might have been. All we can do is wonder if the players who made history found correct answers to the challenges presented by the unfolding of events" (Axworthy and Trudeau 1990) ${ }^{61}$.

\section{Privacy}

In a 1961 essay, McLuhan wrote that

"As we move into a world of multiple centers without margins, every facet of space awareness is altered both in private and public existence. The very concept of privacy, which originated with print culture in the 16th century, can no longer be sustained by the traditional means of partitioning space...

"Today, the entire human community is being translated into "auditory space", or into that "field of simultaneous relations", by electric broadcasting" (McLuhan 2016) ${ }^{62}$.

He was positing print against electric media, especially radio, but a case can be made for screen time's similar effect. The world of private identity began to disappear with the advent of telegraphy, McLuhan wrote, while counterintuitively maintaining that

59 (Ricci 2009), Pierre, p. 158.

60 (Kahn 2019), Been Hoping, p. 143.

61 (Axworthy and Trudeau 1990), Just Society, p. 369.

62 (McLuhan 2016), Nature of Media, p. 61. 
private identity was "a definition of self which was achieved in a small community where everybody knew everyone else ..." (McLuhan and Powers 1989) ${ }^{63}$.

He wrote that printing, which resulted in books one could read in private, led to more compartmentalization of life and he perceived somewhat of a return to that in the 1960s, at least among young people: (McLuhan 2016) ${ }^{64}$.

“Throughout the Middle Ages, there had been less separateness between men and women. Privacy, for example, was unwished. Houses had no hallways; bedrooms served as passageways and sleeping places for children, relatives and visitors, along with married couples. Under such circumstances, the sexual act merged easily with the rest of life. Language now considered intimate or vulgar was part of ordinary conversation" (McLuhan 2016) ${ }^{65}$.

McLuhan predicted that a wired world would shape information globally, which would shape both the world and the information, an echo of Winston Churchill's "We shape our buildings, and afterwards our buildings shape us". That phrasing has a catchy rhythm and meaning that have lasted-as one writer put it in 2020, "We thought we search Google, but now we understand that Google searches us" (Zuboff 2020) ${ }^{66}$. Similarly, another writer noted that Google and Facebook and, in China, the companies Baidu and Tencent, are "attention merchants" which

" ... capture our attention by providing us with free information, services, and entertainment, and then they resell our attention to advertisers. Yet their true business isn't merely selling ads. Rather, by capturing our attention they manage to accumulate immense amounts of data about us, which are worth more than any advertising revenue. We aren't their customers-we are their product" (Harari 2018) ${ }^{67}$.

\section{Personal}

McLuhan and his wife, Corinne, had six children. The letters make a few references to only one of them, Teri. Corinne herself is not mentioned often and never in a context separate from Marshall. Despite references to Trudeau's marriage, there are none for the births of his children and no direct mention of his divorce, events which occurred during the period these men were in touch with each other. According to sources both formal and informal, Trudeau often visited the McLuhan home in Toronto, but the letters are silent on this point too. The letters also have nothing more than passing mentions of their shared interest, albeit with differing emphases, of things Asian. The archives do contain a condolence note from the McLuhans to Trudeau after his mother's death in January 1973 and the official thank you from Trudeau and his siblings but, based on the total picture, I think there is more, still restricted, correspondence in the archives and held by members of both of their families.

In the summer of 1974, the prime minister was preoccupied with an election, which he won, and personal problems.

20 September 1974 (Kahn 2019) 68

Dear Pierre:

Friends in the Ontario government told me yesterday that Davis ${ }^{69}$ is moving for an immediate snap election to prevent any opposition organization and to anticipate the unpopularity he foresees resulting from economic impasse. I enclose a small essay on inflation in which I propose the only dis-equilibrium theory, so far as I know.

63 (McLuhan and Powers 1989), Global Village, p. 113.

64 (McLuhan 2016), Nature of Media, p. 138.

65 (McLuhan 2016), Nature of Media, p. 131.

66 (Zuboff 2020), "Known Unknown”.

67 (Harari 2018), "Tyranny".

68 (Kahn 2019), Been Hoping, p. 115.

69 William Davis, Conservative premier of Ontario from 1971 to 1985. 
Corinne and I are naturally distressed at Margaret's illness, and we shall pray.

yrs Marshall

Earlier that week, the news had featured Margaret's release from a Montreal hospital, giving the public notice that she might have mental health problems.

26 September $1974\left(\right.$ Kahn 2019) ${ }^{70}$.

Dear Marshall,

A short note but I do want to thank you for your thoughtful letter of September 20 and for your essay on inflation-it is on my list of priority reading and study material.

I also owe you my thanks for your letter of June 13. I was absent from Ottawa almost continuously during the last two weeks of June and did not read your letter until after the election. It is a strange coincidence, but I fairly well followed your recommendation about the handling of hecklers, at a public meeting in Peterborough on July 6.

With my deep gratitude to you and Corinne for the prayers you are saying for Margaret—-the latest news is encouraging.

Sincerely, and God bless!

Pierre

July 30/75 (Kahn 2019) $)^{71}$

Dear Pierre:

... Our daughter Teri, whom you met, has spent the last three weeks at the Moscow Film Festival. Her picture on Curtis, the photographer of North American Indians, having been one of three North American films chosen by the Russians, for their Festival. She has certainly found her creative outlet, though it has entailed some very vicious competition and frustration ...

[M.M.]

14 October 1975 (Kahn 2019) 72.

Dear Marshall,

... In closing, I must say how pleased I was to learn about the creative outlet ... and frustration (!) your Teri found at the Moscow Film Festival. Please pass along my warmest congratulations for her so successful picture on Curtis. Your "jests" were, indeed, highly refreshing: I will look forward to making use of them on an "appropriate occasion".

Margaret joins me in wishing you all the very best.

I cannot end this letter without a reference to our friend Jim Davey, since he and I so enjoyed discussing your letters together. He left us at a time when we in the government needed his counsel badly. But then, there is no time when a man like Jim isn't needed ... I am sure he is helping us, and Pat and the family, with his prayers.

In friendship

Pierre

Davey had died that summer after falling from the roof of his home while removing storm windows (Cook 2006) ${ }^{73}$.

(Kahn 2019), Been Hoping, p. 116.

1 (Kahn 2019), Been Hoping, p. 122.

72 (Kahn 2019), Been Hoping, p. 124.

73 (Cook 2006), Teeth, p. 162. 
13 December 1976 (Kahn 2019).

Dear Marshall.

I am sorry to hear that you have not been well and hope that you are steadily improving. I appreciate your taking the time to send me the interesting articles on the use of television in the American presidential campaign. As ever, I rely on you to keep me informed of developments in the field of communications.

With best personal regards, and prayers,

Yours sincerely,

[P.E.T.]

McLuhan had serious health problems for many years, but did not like to dwell on them, which may be why they were so seldom mentioned in the correspondence.

25 July 1977 (Kahn 2019) ${ }^{75}$

Dear Marshall,

Thank you for your May 11 letter and the enclosed note. I apologize for the delay in replying.

You continue to fascinate us with your treatises on the interaction and interrelation between technology and man. Your recent thoughts on the effects of the media on private morality present provocative though frightening observations of our society. One begins to wonder if our age of rapid communication leaves room for anything private- not just morality but thoughts and even creativity.

I welcome your correspondence, Marshall. You open to me an opportunity to turn my thoughts to different channels. I look forward to hearing more on your ideas of "private" morality.

Yours sincerely, and in friendship,

Pierre

When I was twenty, I was greatly influenced by Christian humanists like Maritain, and Christian existentialists like Mounier and Berdiaeff, who-in reaction to Descartes' dualismwere teaching us to "incarnate" our souls into our bodies, and hence to better relate to Natural Law.

The T.V. age has created a new dualism, but the disembodiment is just as effective as the cartesian one. Can we get the T.V. generation interested in books? In natural law? In private morality?

P.

Everything in this letter, from "and in friendship" on, was handwritten. After McLuhan's death, Trudeau said their friendship "'freed me up,'" allowing him to probe wherever his thoughts led without worrying about and getting stopped by possible contradictions (English 2006) ${ }^{76}$.

\section{Public/Private}

A discussion of public and private in the mutual light of each other can quite naturally be a discussion of the individual in relation to the state or corporate entity and that thread does exist in the correspondence, but is beyond the scope of this paper. However, because working to understand the best balance was so fundamental to Trudeau's being, one of his statements on the subject needs to be included here. Several years before becoming prime minister, he wrote that the state "... must take great care not to infringe on the conscience of the individual. I believe that, in the last analysis, a human being in the privacy of his 
own mind has the exclusive authority to choose his own scale of values and to decide which forces will take precedence over others. A good constitution is one that does not prejudge any of these questions, but leaves citizens free to orient their human destinies as they see fit" (Trudeau 1968) ${ }^{77}$.

Years later, reminiscing about the criminal codes changes he introduced to Parliament just before becoming Liberal leader, which included liberalized laws on homosexuality and abortion, Trudeau wrote that "What is considered sinful in one of the great religions to which citizens belong isn't necessarily sinful in the others. Criminal law therefore cannot be based on the notion of sin; it is crimes that it must define. But I also had to make it understood that in decriminalizing a given action, the law was in no way challenging the moral beliefs of any given religion" (Trudeau 1993) ${ }^{78}$.

The following letter mixes the public and the private in intriguing ways. The dinner it refers to took place very soon after the October Crisis, which must be at least one of the "political developments" referred to, and McLuhan, for the first and only time in the correspondence, tells the prime minister he will "report" back. Just as interesting, McLuhan points out how good it felt that all the dinner guests felt free to be completely themselves that evening.

3 December 1970 (Kahn 2019) $)^{79}$

Dear Mr. Trudeau:

Since the dinner on Friday, November 27, much of the time I have been down with flu. My first act since recovery is to thank you for the wonderful evening and the incomparable honour which you conferred upon me and my family. Teri and Corinne insist that their lives have an entirely new dimension as a result of that event! Part of the satisfaction, however, was in the assured feeling that each of us was in fact being entirely "himself". The events of the next day - the unveiling of the dramatic hat and cloak, the kick-off, and the Alouette triumph ${ }^{80}$-all seemed to be an extended part of the same euphoric experience of our dinner meeting.

Your comments on the political developments in Canada have been recurring in my thoughts. I know some good fruit will come of this, and I shall report to you before too long.

In friendship and esteem,

[M.M.]

11 December 1970 (Kahn 2019) $)^{81}$

Dear Mr. McLuhan:

I was pleased and touched at your kindness in sending to me the inscribed copies of "Culture Is Our Business", "From Cliché to Archetype", and "The Literary Criticism of Marshall McLuhan 1943/1962".

I will be delighted to have them in my own personal library, not only so that I can have them close at hand but also because they will be a pleasant reminder of an enjoyable evening that I spent in company with Mrs. McLuhan, Teri, yourself, and the Daveys.

It was very thoughtful indeed of you to think of me in this way.

Yours sincerely,

Pierre E. T.

77 (Trudeau 1968), Federalism, p. 11.

78 (Trudeau 1993), Memoirs, p. 83.

79 (Kahn 2019), Been Hoping, p. 84.

80 The Montreal Alouettes football team defeated the Calgary Stampeders 23 to 10 in Toronto to win the Grey Cup, the top prize in Canadian professional football.

81 (Kahn 2019), Been Hoping, p. 84. 
In "Culture Is Our Business", McLuhan sent out a probe that would figure in letters to the prime minister: "The entire Western world is going East (tribal) and inward. The East is detribalizing-going West and outward. No such macroscopic revolution ever occurred before. All identity images, private and corporate, dissolve. Violent struggle to regain these images ensues" (McLuhan 1970) ${ }^{82}$.

$$
5 \text { March } 1971 \text { (Kahn 2019) } 83
$$

\section{Dear Pierre:}

We rejoice in your marriage and in the enormous discomfiture of many of your enemies! We also rejoice in the loveliness of your bride, and in sharing the Catholic faith with both of us.

Many blessings.

[M.M]

Trudeau had insisted Margaret convert to Catholicism. "That Trudeau's behaviour throughout his life was tied up with his religiosity was usually unfathomable to those who were taken in by his public mask" (Clarkson and McCall 1990) ${ }^{84}$. He apparently wanted to keep his attendance at church private and did not allow photographers to take pictures of him going to church (Trudeau 1996) ${ }^{85}$.

$$
8 \text { March } 1971 \text { (Kahn 2019) } 86
$$

\section{Dear Jim:}

We have naturally been delighted by the great Pierre and Margaret wedding event. Surely there is nothing in the history of democratic politics to match the mise en scène of this event. It was not only a personal but a political triumph, putting both the opposition and the media in Pierre's pocket, as it were. The media people have to be grateful for being duped, since their unpreparedness was very much part of the show ...

Cordial greetings, yrs

Marshall

17 October 1973 (Kahn 2019) $)^{87}$

\section{CONGRATULATIONS. HAPPY BIRTHDAY AND CONGRATULATIONS ON CHINA TRIUMPH. \\ MARSHALL MCLUHAN}

A week earlier, Trudeau had flown to the People's Republic of China, making him the first Canadian prime minister to visit the PRC. His birthday was October 18. He thanked McLuhan for the above telegram, which so succinctly combined the personal with the public. McLuhan often sent birthday greeting to the prime minister, but this does appear to have been reciprocal.

26 March 1974 (Kahn 2019) 88

Dear Pierre:

There may be some relevance in the questions that Clare Booth Luce ${ }^{89}$ asked recently, and my replies. First, her questions:

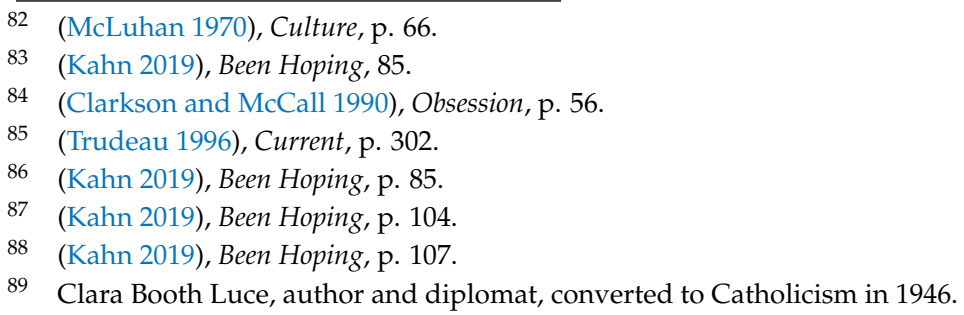


... (2) Please explain why you think (or don't think) that the impeachment of R.N. is going to purify democratic politics and "restore integrity" to Government, and how this will help us control inflation, pollution, repair the breach with NATO, etc.

... I have discovered over the years that the effects of innovation are always subliminal, and people resent having this pointed out, feeling that you are invading their privacy in so doing.

Let us turn, then, to your question about the impeachment of Richard Nixon. Nixon and the U.S.A. are caught between the First World and the Fourth World. That is, while having all its commitments to the old Graeco-Roman hardware, it is totally involved in the new electronic information environment which is dissolving all the controls and all the goals of the First World. The Fourth World, or the electronic world, reduces personal identity profiles to vestigial level and, by the same token, reduces moral commitments in the private sector almost to zero. Paradoxically, however, as private morals in the private sector sink down, new absolutist demands are made of ethics in the public or political sector. R.N. had the misfortune to bring the old private morals into the public place just when this reversal had occurred. There is also the misfortune of his image which is intensely private and non-corporate and therefore totally unsuited to TV (Charisma is looking like a lot of the people-anything except one's self!).

The U.S., the only great country in the world based on a written constitution, has no way of coping legally or politically with the new oral and acoustic situations created by the electronic bugging and the general $\mathrm{X}$-ray procedures in the entire private sector. Man-hunting has become the biggest business on the planet in the electronic age, and is a return to the Paleolithic conditions of the hunter ...

You are most generous in even noticing my Civic Award, and it is quite princely of you to have written me about it. Mrs. McLuhan joins me in heartiest and most cordial regards to you and your family ...

The prime minister replied to McLuhan immediately, particularly attracted by some of the comments on money and by the use of First, Second, Third and Fourth Worlds as a way to interpret current events. But there was an election coming in July and Trudeau let the correspondence lapse for a while, a not unusual pacing of their letters.

17 February 1975 (Kahn 2019) $^{90}$.

Dear Marshall

Many thanks for your letter of January 22 commenting about the two articles on multi-national corporations which appeared in the December 2 and 9, 1974 issues of the New Yorker.

Your remarks are typically incisive. I have been able to secure a copy of the articles and propose to give them a careful reading.

Margaret and I are grateful to you and Corinne for your continued prayers. With warm regards to you both.

Sincerely,

Pierre

Serious social issues, including abortion rights and capital punishment, were significant parts of the political climate in Canada at the time and, in the summer of 1976, capital punishment was abolished, after having been under a moratorium for years. Trudeau was in favor of this move. McLuhan was not. 
Dear Pierre:

I think this may be a rather important note, and its brevity should be no indication of its significance. Apropos the problem of hanging and capital punishment, there seems to be a universal assumption that hanging is punitive, retaliation for misdeeds. I suggest that this is a very minor aspect of the matter. The central significance of capital punishment is the ritual that it entails, and this ritual serves primarily to enhance the significance and importance of human life by drawing attention to the decisive and infinite implications of the moment of death...

We live in a time when the coalescing of all people on earth into a single mass-public has diminished human private identity almost to the vanishing point. Anybody at a ball game, for example, is a nobody, and the entire planet has become our ball park. Under electric conditions of our inter-involvement of all mankind, the information environment has blanketed and smothered private identity. This effect has made human life appear very cheap indeed. The TV generation cannot feel very much importance attaching to the private person. On the other hand, the loss of private identity which has come rather suddenly upon Western man has produced a deep anger at this rip-off of his private self.

There are two kinds of violence relating to the same situation, first, the kind that comes from the unimportance of everybody, and second, the kind that comes from the impulse to restore one's private meaning by acts of violence. On the frontier everybody is a nobody and violence is the order of the day. Electronic man lives on such a frontier at all times, doubting his identity and his survival alike. Psychologically considered, violence is an attempt to restore order to achieve identity.

With prayers for you and Margaret

Yrs

Marshall

13 December 1977 (Kahn 2019) ${ }^{92}$

Dear Pierre:

We deeply appreciated your princely hospitality at the "Three Little Rooms", (Molinaro et al. 1987) ${ }^{93}$ and your presence at our seminar left a very deep impression of your cordial and lively person.

One of the things we have been working over in the seminar has been the problem of inflations and joblessness, two closely related things. To put both matters very briefly, the nature of work has changed drastically since we have begun to live in a simultaneous information environment ... The major form of work in the electronic age has become "keeping an eye on other people", whether audience research or public relations or simply espionage. It is sometimes called "data processing"...

The main verb in all this is the speed of light, which also alters the role of politician from a party representative to a charismatic image. This image obsolesces parties and policies alike. This is very compressed, but I know you are busy-perhaps not too busy to hear a joke that has just turned up. It concerns a traveler returning from the U.K. with a dozen bottles of whiskey. At the Customs he is asked: "What have you got here?" He replies: "Holy water". The 
Customs officer opens one of the bottles and takes a swig, and says: "That's not holy water-that's whiskey!" At this the traveler exclaimed rapturously: "It's a miracle!"

Corinne and I pray that your Christmas and New Year will be liberally strewn with miracles!

Trudeau's appearance at McLuhan's weekly university seminar has become legendary among students who were there.

The following letter is McLuhan's last to Trudeau; he suffered a major stroke three weeks later which left him unable to communicate effectively in any medium.

7 September 1979 (Kahn 2019) 94

Dear Pierre:

I think there is no question but that your beard has cooled your image many degrees! There may be a time when you would wish to hot it up again ...

Another matter is that this is the last year for the Centre as it is presently related to the University of Toronto. This is mainly a financial matter, although there is also the fact that they cannot find anybody to replace me. I personally know of some possible replacements and this could be one of the matters I would like to discuss with you when we get together ...

The university moved unceremoniously quickly to shut down McLuhan's Centre once he was disabled. Trudeau was among those who failed in the attempt to get the school to change its mind.

28 April 1980 (Kahn 2019) ${ }^{95}$.

Dear Marshall,

I have been hearing about the difficulties you are presently experiencing at the Centre and would like you to know that you are in my thoughts. You had intimated that there were financial problems, but I had no idea that the University was considering closing the Centre.

Who knows better than you and I the bitter irony of the old saw about a prophet in his own land ... However, you can be assured of a prominent place not only in Canadian history, but in the annals of technocracy. It is heartening to see that the press is treating you with the respect you are owed.

All the best to you and Corinne.

Yours sincerely, and God bless,

Pierre

7 January 1981.

My dear Corinne,

It is with great sadness that I write to express my sympathy to you and your family. Despite the setback which Marshall suffered more than a year ago, the news of his death was still a terrible shock.

Much will be said and written, and rightly so, about his marvelous intellect, his years of teaching, his global eminence as a social theorist, as a seminal scholar and writer. But the dominant thoughts in my own mind are of you and your children, and of my own sense of loss. 
I have longed valued his friendship, and have warm memories of our stimulating conversations. His letters were a constant delight, even when they included those terrible puns he used to urge me to use in political debate.

Marshall's life and work increased my sense of pride in being a Canadian. His crackling mind provided me with much pleasure and many lasting insights. His work, I am sure, will live on to challenge thoughtful men and women of future generations.

At this time, perhaps what is of most consolation to you is your knowledge of his great faith, and of the goodness of his life. He was a man whose fame did not dilute his profound awareness that our destiny in life is to love and to serve.

In the name of the government and people of Canada, I want to express the sympathy of a nation which is saddened by his death, and grateful for his life. For my part, I simply pray that God will grant strength, lasting peace and serenity of spirit to you and your family.

Yours sincerely,

Pierre

Trudeau was one of those who worked to ensure that McLuhan's papers were placed in archives in Canada.

\section{Secret}

The available correspondence does not mention the 1970 October Crisis. This traumatic event in Canadian history and prominent marker in both Trudeau's time in government and legacy involved domestic terrorism in Quebec and Trudeau's invocation of the federal War Measures Act, the first time the law had been invoked in peacetime. One of the events precipitating the crisis - the kidnapping of British trade commissioner James Richard Cross-made Canada "the first Western nation to experience a political kidnapping at home" (Crelinsten and Schmid 1992) ${ }^{96}$. Pierre Laporte, Quebec's deputy prime minister of Quebec and a friend of Trudeau, was kidnapped and murdered.

Trudeau taped a speech to the country, broadcast the night before Laporte's body was found. The public "icy calm" man Canadians saw on-screen worked on that image during the taping: "During the brief delay while the television crew changed its tape magazines, he did push ups on his office rug and, with his back against the wall, deep-breathing exercises" (Buckley 1970) ${ }^{97}$.

Davey directed "the Strategic Operations Centre that devised the federal government's response" (Cook 2006) ${ }^{98}$ and he continued to be involved once the immediate crisis passed, including accompanying Cross on his flight back to England. What to tell the media and how and when were critical matters, so I have trouble believing McLuhan held back from giving Trudeau advice, solicited or not, directly or through Davey. There is just a hint in McLuhan's December 3, 1970 letter to Trudeau, as mentioned earlier, and there is foreshadowing in the following memo, which refers to recent events in Montreal, including the FLQ bombing of the stock exchange and the riot at Sir George Williams [now Concordia] University.

31 March 1969 (Kahn 2019) ${ }^{99}$

MEMORANDUM FOR MR. LALONDE

From: J.M. Davey

Re: Toronto Visit—Thursday, April 3rd

96 (Crelinsten and Schmid 1992), “Terrorism”, p. 309.

97 (Buckley 1970), “Testing”.

98 (Cook 2006), Teeth of Time, p. 117.

99 (Kahn 2019), Been Hoping, p. 69. 
I will be in Toronto next Thursday to visit Dr. Marshall McLuhan. This is a follow-up from an exchange of correspondence between Dr. McLuhan and the Prime Minister. I want to discuss the whole question of the use of television as a vehicle of public information but with particular emphasis on such events as Federal-Provincial Conferences.

While I am there I also intend to meet Superintendent Harold Genno, of the Metropoli$\tan$ Police. I gather, from the attached clipping, that he has made a study of the question of police tactics and relations during public manifestations. Don Wall (Wall 2021)100 is aware of my visit.

While we are on the subject, you might want to consider asking a number of questions of the Department of National Defense. Last week the Government was in the position where it might have had to furnish armed forces to assist the Montreal police. In this instance, the Government would have had no option had a written request been made for such support. While everyone concerned is happy that the eventuality did not arise, I can't help asking myself what would have been the outcome if it had.

Question:

If the Armed Forces are under this obligation, what in their training would give them the necessary experience and competence?

Do the Armed Forces receive specialized training in crowd control and relations with manifesters under such conditions?

Which troops would have been used on this occasion, were they in particular, adequately trained to carry out the task?

What will we do in future if we receive another such request?

One wonders whether such a memorandum would even have been written today. Starting with photocopying, as McLuhan presciently pointed out, more boundaries were erased:

"For example, Xerox extends the function of the typewriter almost to the point where the secret, personal memo is moved into the public domain, as with the Pentagon Papers. When notes for briefing individuals or groups are first typed and then Xeroxed, it is as if a private manuscript were put in the hands of the general reader...Contemporary dialogue in committees depends very much on this new Xerox service; but the very public character of the service is difficult to restrict. The result is that confidential briefing is now beginning to take an oral rather than a written form" (McLuhan 2016) ${ }^{101}$.

\section{Conclusions}

There is a strong urge when examining a relationship to try to prove that one of those involved had an influence on the other or that there was an influence that was mutual. This cannot be proven with Trudeau and McLuhan, as it cannot with most friendships, though I am sure Trudeau did learn something from McLuhan about handling media and presenting himself to the public through them.

A fuller picture will emerge as archival restrictions end. Public archives such as LAC are in a strange situation, tugged between openness and gatekeeping and answerable to a number of bosses and regulations. A change in the laws in France in 1979 led to results that were not clear cut and remind me of my own work with the very helpful archivists in Ottawa: "Depending on whether one was working on a sensitive subject or one considered sensitive (which was often a question of the individual archivist's mood at the lower echelon, or the liberalism of the institution which created the document at the

100 Don Wall 2021, https://books.google.com/books?id=saM_hcySs20C\&pg=PA295\&lpg=PA295\&dq=Don+Wall+and+RCMP\&source=bl\&ots= QfplIA6x5k\&sig=Hq_TRwIfizZKzjJPhK_Yea80RBA\&hl=en\&sa=X\&ved=0ahUKEwjvrKDNgu7KAhXFgZAKHTckAwEQ6AEIRDAI\#v=onepage\& $\mathrm{q}=$ Don $\% 20$ Wall\%20and\%20RCMP\&f=false) (accessed on 21 May 2021). Wall was apparently involved in security matters, including serving as assistant secretary for security and intelligence in the Privy Council Office. 
higher echelon), the response might be "everything is open" or "everything is classified"." (Combe 2013) ${ }^{102}$.

Today, it is not only our attitude about what we have the right to know which has changed, it is also our relationship with that information. As one archivist wrote, "Slowly but surely, the complete trust and reliance on large information gatekeepers, like governments and big media players, has morphed into recognition that these are simply some of the many voices and not necessarily the authoritative ones ... The making and keeping of reliable records is crucial to activists, as much as it is to governments and businesses" (Findlay 2013) ${ }^{103}$.

Unfortunately, fuzzy definitions and issues of "national security" often win out over equally poorly defined "human rights", (Combe 2013) ${ }^{104}$ and leaders globally "... have to muster the requisite political will to update norms, guidelines, regulations, and laws at the international level, because aggressors in cyberspace do not respect national borders .... In the same spirit, countries around the world need to agree on new norms: what level of cyberattack amounts to an act of war, for example, and what measures would serve as an appropriate response to such an attack" (Schaake 2020) ${ }^{105}$.

Trudeau and McLuhan would not have liked the escalating actual violence of our time and the contemporary default to the language of battle and attack in far too many areas. But McLuhan would not have been surprised. "One of the many flips of our time is that the electric information environment returns man to the condition of the most primitive prober and hunter", he wrote. "Privacy invasion is now one of our biggest knowledge industries" (McLuhan 1970) ${ }^{106}$.

Trudeau would not have been surprised either. Unlike McLuhan, he is not generally described as prescient or prophetic, but it has been 50 years since he wrote that "There are few countries left in the world where citizens can still live their lives with a minimum of restrictions; without doubt, the logic of the thermonuclear age and the universe of the concentration camp will sooner or later put an end to our anachronistic freedoms. But please, let's give in only with regret, and at the latest possible date; and let's make sure the first concessions are not imposed on us by a handful of political amateurs struggling to prove their good intentions to us" (Trudeau 1996) ${ }^{107}$.

He was aiming at the politicians in Quebec's government but, sadly, his words feel as fresh as the man himself.

Funding: This research received no external funding.

Institutional Review Board Statement: Not applicable.

Informed Consent Statement: Not applicable.

Data Availability Statement: Not applicable.

Conflicts of Interest: The author declares no conflict of interest.

\section{References}

Axworthy, Thomas S., and Pierre Elliott Trudeau, eds. 1990. Towards a Just Society: The Trudeau Years. Markham: Penguin Books Canada Ltd.

Bilefsky, Dan, and Ian Austen. 2019. New Video Surfaces Showing Trudeau in Blackface, Compounding Scandal. Available online: https:/ / www.nytimes.com/2019/09/19/world/canada/justin-trudeau-brownface-image.html?searchResultPosition=4 (accessed on 21 May 2021).

\footnotetext{
102 (Combe 2013), “Confiscated", p. 126.

103 (Findlay 2013), "People”, p. 10.

104 (Combe 2013), “Confiscated”, p. 128.

105 (Schaake 2020), “Lawless".

106 (McLuhan 1970), Culture, p. 24.

107 (Trudeau 1996), Current, 115.
} 
Boutilier, Alex. 2020. Privacy law will have penalties for companies that abuse Canadians' data. Toronto Star. Available online: https:/ /www.thestar.com/politics/federal/2020/11/16/privacy-law-will-have-penalties-for-companies-that-abusecanadians-data.html (accessed on 30 March 2021).

Bronskill, Jim. 2019. CSIS Destroyed Secret File on Pierre Trudeau, Stunning Historians. Toronto: Canadian Press, Available online: https:/ / www.cbc.ca/news/politics / pierre-trudeau-csis-file-1.5177205 (accessed on 23 March 2021).

Buckley, Tom. 1970. The Testing of Pierre Trudeau. New York Times. Available online: https://timesmachine.nytimes.com/ timesmachine/1970/12/06/105325597.html (accessed on 31 March 2021).

Carr, Nicholas. 2017. How Tech Created a Global Village-and Put Us At Each Other's Throats. Boston Globe. Available online: https:/ / www.bostonglobe.com/ideas/2017/04/21/how-technology-created-global-village-and-put-each-other-throats / pu7MyoAkdyVComb9aKyu6K/story.html (accessed on 30 March 2021).

Clarkson, Stephen, and Christina McCall. 1990. The Magnificent Obsession: Trudeau and Our Times. Toronto: McClelland \& Stewart Inc.

Clarkson, Stephen. 2000. Charisma and Contradiction: The legacy of Pierre Elliott Trudeau. Queen's Quarterly 107: 590-607. Available online: http:/ / mtolliday.weebly.com/uploads/2/4/9/3/24933340/charisma_and_contradiction_-_pe_trudeau.pdf (accessed on 30 March 2021).

Combe, Sonia. 2013. Confiscated Histories: Access to 'Sensitive' Government Records and Archives in France. Zeithistorische Forschungen/Studies in Contemporary History 10: 123-30. Available online: https:// zeithistorische-forschungen.de/1-2013/4435 (accessed on 31 March 2021).

Cook, Ramsay. 2006. The Teeth of Time: Remembering Pierre Elliott Trudeau. Montreal: McGill-Queen's University Press.

Crelinsten, Ronald D., and Alex P. Schmid. 1992. Western responses to terrorism: A twenty-five year balance sheet. Terrorism and Political Violence 4: 307-40. [CrossRef]

English, John, Richard Gwyn, and P. Whitney Lackenbauer, eds. 2004. The Hidden Pierre Elliott Trudeau: The Faith Behind the Politics. Toronto: Novalis.

English, John. 2006. Citizen of the World: The Life of Pierre Elliott. Trudeau (1919-1968). Toronto: Alfred A. Knopf Canada.

Findlay, Cassie. 2013. People, records and power: What archives can learn from WikiLeaks. Archives and Manuscripts 41: 7-22. [CrossRef]

Harari, Yuval Noah. 2018. Why Technology Favors Tyranny. The Atlantic. Available online: https://www.theatlantic.com/magazine/ archive/2018/10/yuval-noah-harari-technology-tyranny/568330/ (accessed on 31 March 2021).

Kahn, Elaine. 2019. Been Hoping We Might Meet Again: The Letters of Pierre Elliott Trudeau and Marshall McLuhan. Toronto: Novalis.

Lomas, Elizabeth. 2019. Navigating Confidentiality, Legal Privilege and GDRP to Maintain Legal Records for Future Generations: The Case for Archiving. Available online: https://discovery.ucl.ac.uk/id/eprint/10057964/1/Navigating\%20confidentiality\%20 elomas.pdf (accessed on 30 March 2021).

Marchand, Philip. 1998. Marshall McLuhan: The Medium and the Messenger. Cambridge: The MIT Press.

McLuhan, Marshall, and Bruce R. Powers. 1989. The Global Village: Transformations in World Life and Media in the 21st Century. New York: Oxford University Press.

McLuhan, Marshall. 1970. Culture Is Our Business. New York: McGraw-Hill.

McLuhan, Marshall. 2003a. The Book of Probes. Corte Madera: Gingko Press Inc.

McLuhan, Marshall. 2003b. The Medium Is the Massage: An Inventory of Effects. Corte Madera: Gingko Press Inc.

McLuhan, Marshall. 2016. On the Nature of Media: Essays in Understanding Media. Richard Cavell. Berkeley: Gingko Press, Inc.

Merriam-Webster. n.d. Available online: https:/ / www.merriam-webster.com/ (accessed on 30 March 2021).

Molinaro, Matie, Corinne McLuhan, and William Toye, eds. 1987. Letters of Marshall McLuhan. Toronto: Oxford University Press.

Onions, Charles Talbut, ed. 1970. Shorter Oxford English Dictionary, 3rd ed. London: Oxford University Press.

Ricci, Nino. 2009. Pierre Elliott Trudeau. Toronto: Penguin Group.

Schaake, Marietje. 2020. The Lawless Realm: Countering the Real Cyberthreat. Foreign Affairs. Available online: https://www. foreignaffairs.com/articles/world/2020-10-13/lawless-realm (accessed on 31 March 2021).

Shaw, Brian. 1969. The Gospel According to Saint Pierre. Richmond Hill: Simon \& Schuster of Canada Ltd.

Singer, Natasha, and Choe Sang-Hun. 2020. Privacy Is Seen as Early Victim of the Outbreak. New York Times, March 25.

Trudeau, Pierre Elliott. 1968. Federalism and the French Canadians. Toronto: Macmillan of Canada.

Trudeau, Pierre Elliott. 1972. Conversation with Canadians. Toronto: University of Toronto Press.

Trudeau, Pierre Elliott. 1993. Memoirs. Toronto: McClelland \& Stewart Inc.

Trudeau, Pierre Elliott. 1996. Against the Current: Selected Writings 1939-1996. Toronto: McClelland \& Stewart Inc.

Wall, Don. 2021. Part Four: Separatist, Scandals and Refor. Available online: https://books.google.com/books?id=saM_hcySs20C\& pg=PA295\&lpg=PA295\&dq=Don+Wall+and+RCMP\&source=bl\&ots=QfplIA6x5k\&sig=Hq_TRwIfizZKzjJPhK_Yea80RBA\&hl= en\&sa=X\&ved=0ahUKEwjvrKDNgu7KAhXFgZAKHTckAwEQ6AEIRDAI\#v=onepage\&q=Don\%20Wall\%20and\%20RCMP\& $\mathrm{f}=$ false) (accessed on 21 May 2021).

Wright, Donald, and Thomas Cheney. 2009. Pierre Trudeau, Michael Ignatieff, and the Flame of 1968. Acadiensis 38: 159-67. Available online: https://journals.lib.unb.ca/index.php/Acadiensis/article/view/12741 (accessed on 19 March 2021).

Zuboff, Shoshanna. 2020. The Known Unknown: Surveillance capitalists control the science and the scientists, the secrets and the truth. New York Times. January 26. Available online: https:/ /www.nytimes.com/2020/01/24/opinion/sunday/surveillance-capitalism. html? searchResultPosition=5 (accessed on 31 March 2021). 